\title{
Evaluate the Effectiveness of Serum Magnesium Level in Patients with Newly Diagnosed Acute Leukemia
}

Dr. Md. Abdul Kader Zilani ${ }^{1 *}$, Dr. Jannatul Ferdous ${ }^{2}$, Dr. Mohammad Nurul Islam Khan ${ }^{3}$, Dr. Masuda Begum ${ }^{4}$, Dr. Sushanta Kumar Barman ${ }^{5}$, Dr. Showrab Biswas ${ }^{6}$

${ }^{1}$ Assistant Professor, Department of Haematology, Rangpur Medical College, Rangpur, Bangladesh

${ }^{2}$ Assistant Registrar, Department of Anaesthesiology, Rangpur Medical College Hospital, Rangpur, Bangladesh

${ }^{3}$ Assistant Registrar, Department of Medicine, Rangpur Medical College Hospital, Rangpur, Bangladesh

${ }^{4}$ Professor, Department of Haematology, BSMMU, Dhaka, Bangladesh

${ }^{5}$ Registrar, Department of Medicine, Rangpur Medical College Hospital, Rangpur, Bangladesh

${ }^{6}$ Registrar, Department of Haematology, Chottogram Medical College Hospital, Chottogram, Bangladesh

*Corresponding author: Dr. Md. Abdul Kader Zilani

Abstract

Background: Acute leukaemia is a clonal malignant disorder affecting all age groups. It is characterized by the accumulation of immature blast cells in the bone marrow. This results in bone marrow failure, reflected by peripheral blood cytopenias and circulating blast cells. In most cases the etiology is not obvious, but internal and external factors associated with damage to DNA can predispose to acute leukaemia. Objective: In this study our main goal is to evaluate the effectiveness of serum magnesium level in patients with newly diagnosed acute leukemia. Method: This Observational cross-sectional study was done at Department of Haematology, BSMMU, Dhaka from September 2016 to August 2017. During the study period of total 85 patients were enrolled for the study. Results: Most of the patient's age was found $36.17( \pm 19.15)$ years, majority age group was found $10-40$ years of age which was $(62.4 \%)$. Regarding gender $55 \%$ were found male and $45 \%$ were found female and educational status $45(54.12 \%)$ were primary level, $21(24.71 \%)$ were SSC, $5(5.88 \%)$ were HSC and $07(8.24 \%)$. Majority $(60 \%)$ of the patients were found married. Majority $59 \%$ of the patients came from poor class socioeconomic status followed by $40 \%$ were came from middle class socioeconomic status. Regarding occupational status 33(38.82\%) were house wife, 10(11.76\%) were day laborer, $12(14.12 \%)$ were farmer and $19(22.35 \%)$ was student. Regarding acute leukemia majority $60(70.6 \%)$ were found AML and 25(29.4\%) ALL. Conclusion: From our result we can conclude that, significantly lower serum magnesium level was found in newly diagnosed acute leukemia patients. Among them significantly lower in ALL patients than AML patients. Half of the acute leukemia patients were found hypomagnesaemia.

Keywords: Acute leukemia, hypocalcemia, serum magnesium, hypomagnesaemia.

Copyright @ 2020: This is an open-access article distributed under the terms of the Creative Commons Attribution license which permits unrestricted use, distribution, and reproduction in any medium for non-commercial use (NonCommercial, or CC-BY-NC) provided the original author and source are credited.

\section{INTRODUCTION}

Hematological malignancies (HM) comprise approximately $6.5 \%$ of all cancer incidences worldwide in 2012 [1]. WHO predicts that the number of bloodrelated cancer cases would increase about $48 \%$ in less developed countries by 2030 as compared to 2012[1]. Leukemia is a cancer of the bone marrow and blood, characterized by the uncontrolled growth of specific types of white blood cells. While leukemia occurs about 10 times more often in adults than in children [2]. Acute leukaemia is a clonal malignant disorder affecting all age groups. It is characterised by the accumulation of immature blast cells in the bone marrow. This results in bone marrow failure, reflected by peripheral blood cytopenias and circulating blast cells. In most cases the etiology is not obvious, but internal and external factors associated with damage to DNA can predispose to acute leukaemia[3]. Trace elements at optimum levels are required for numerous metabolic and physiological processes in the human body. Zinc $(\mathrm{Zn})$, Copper $(\mathrm{Cu})$ and Manganese $(\mathrm{Mn})$ are important cofactors for several enzymes that play a role in maintaining DNA integrity [4]. In addition, they are involved in membrane transport, nerve conduction and muscle contraction and also in the function of subcellular systems such as mitochondria. $\mathrm{Cu}, \mathrm{Zn}, \mathrm{Mn}$ and selenium also act as antioxidants [5]. Therefore, imbalances in the optimum levels of these trace elements may adversely affect biological processes and are associated with many fatal diseases, such as cancer. There are several reports on serum trace element levels in malignant diseases including leukemia and lymphomas [6]. 
Hypomagnesemia is a relatively common electrolyte abnormality in leukemic patients. It has been reported that low serum magnesium levels may be detected in as many as $30 \%$ of AL patients [7]. Several studies have shown an increase cancer rate in regions with low magnesium levels in soil \& drinking water. Magnesium is actually the key to the body's proper assimilation and use of calcium as well as other important nutrients. Patients with hypomagnesaemia consume too much calcium without sufficient magnesium the excess calcium is not utilized correctly \& may actually become toxic, causing painful conditions in the body. Hypocalcemia is a prominent manifestation of magnesium deficiency in humans [8].

\section{OBJECTIVES}

\section{General objective}

To determine the status of serum magnesium level in patients with newly diagnosed acute leukemia.

\section{Specific objectives}

- To measure magnesium level in study subjects.

- To correlate magnesium level with sodium, potassium, chloride

- To correlate magnesium level with calcium and albumin.

\section{Methodology}

\begin{tabular}{|l|l|}
\hline Type of study & Observational cross-sectional study \\
\hline Place of study & Department of Haematology, BSMMU, Dhaka \\
\hline Study period & September 2016 to August 2017 \\
\hline Study population & All newly diagnosed acute leukemia patients attending department of Haematology \\
\hline Sampling technique & Purposive \\
\hline
\end{tabular}

\section{METHOD}

\section{SELECTION CRITERIA \\ Inclusion Criteria}

- All patients with newly diagnosis of acute leukemia.

- The diagnosis confirmed by bone marrow study and/or immunophenotyping.

- Giving informed written consent to participate.

\section{Exclusion Criteria}

- Patients already received chemotherapy.

- Patients already received any mineral supplementation.

- Moribund patients.

- Patient refuses to participate.

- Subject with diabetes mellitus

- $\quad$ Subject with diuretic therapy

\section{Data Collection procedure}

A pre-designed structured data collection sheet was used. For each and every subject separate data collection sheet was prepared. After selection of study subjects data was collected by details history taking and clinical examination. Written consent was taken from those who was agree to participate in the study. The patients were chosen according to purposive sampling as diagnosed case of acute leukemia attending department of Haematology. The diagnosis was confirmed by bone marrow study. All patients' data including demographical, clinical and laboratory data was collected to evaluate basic hemogram and trace elements status specially magnesium

\section{Statistical Analysis}

All data were processed by utilizing SPSS program (Version 23.0) and expressed as frequencies or percentages as well as mean (SD/SEM) as applicable. Unpaired t-test was used for continuous variables. Pearson's correlation coefficients were used between serum magnesium level with other sodium, potassium, chloride, calcium and albumin. The level of significance was determined as $<0.05$. $\mathrm{p}$ value $<0.05$ was declared as statistically significant.

\section{RESULT}

\section{Age distribution of the study population}

Table 1 showed mean age was found $36.17( \pm 19.15)$ years, majority age group was found 1040 years of age which was $(62.4 \%)$.

Table-I: Age distribution of the study population $(n=85)$

\begin{tabular}{|l|c|c|}
\hline Age in years & Number & Percentage \\
\hline 10-20 years & 27 & 31.8 \\
\hline 21-30 years & 13 & 15.3 \\
\hline 31-40 years & 13 & 15.3 \\
\hline 41-50 years & 15 & 17.6 \\
\hline 51-60 years & 06 & 07.1 \\
\hline$>60$ years & 11 & 12.9 \\
\hline Total & 85 & 100.0 \\
\hline Mean \pm SD & $36.17( \pm 19.15)$ & Range $(10-78)$ \\
\hline
\end{tabular}




\section{Sex distribution of the study population}

Regarding gender $55 \%$ were found male and $45 \%$ were found female.

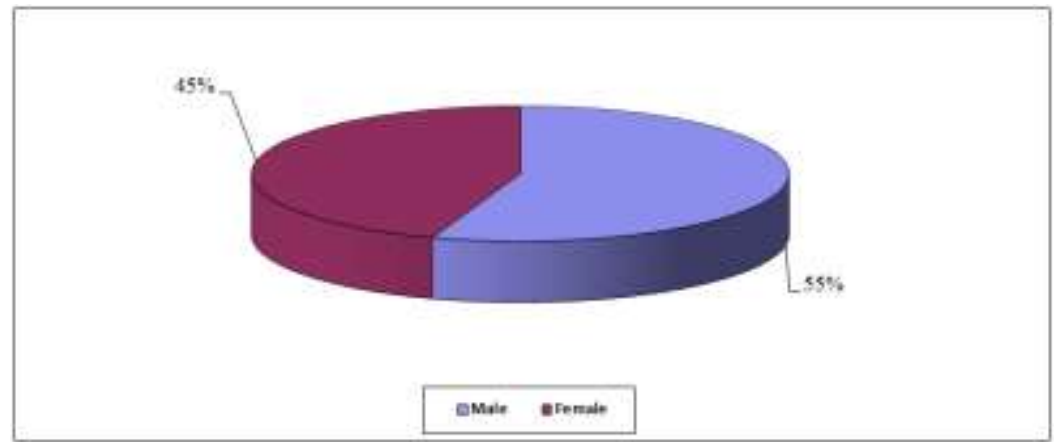

Fig-3: Sex distribution of the study population $(n=85)$

\section{Educational status of the study population}

Figure 1 showed regarding educational status $45(54.12 \%)$ were primary level, $21(24.71 \%)$ were SSC, 5(5.88\%) were HSC and $07(8.24 \%)$.

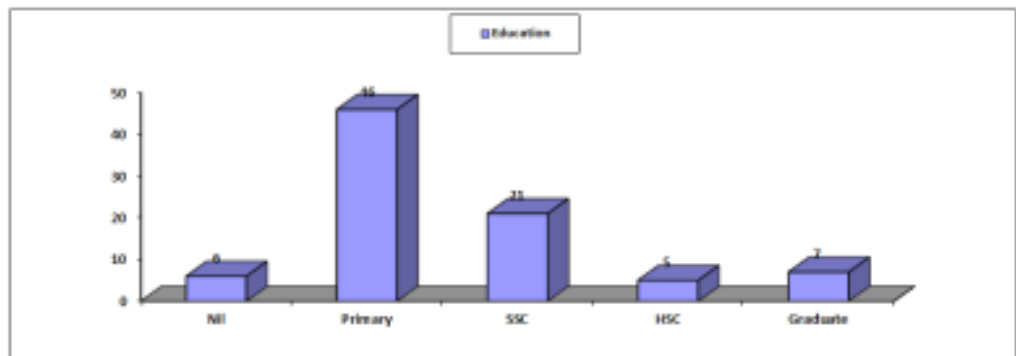

Fig-1: Distribution of educational status of the study population $(n=85)$

\section{Marital status of the study population}

Figure 2 showed majority $(60 \%)$ of the patients were found married

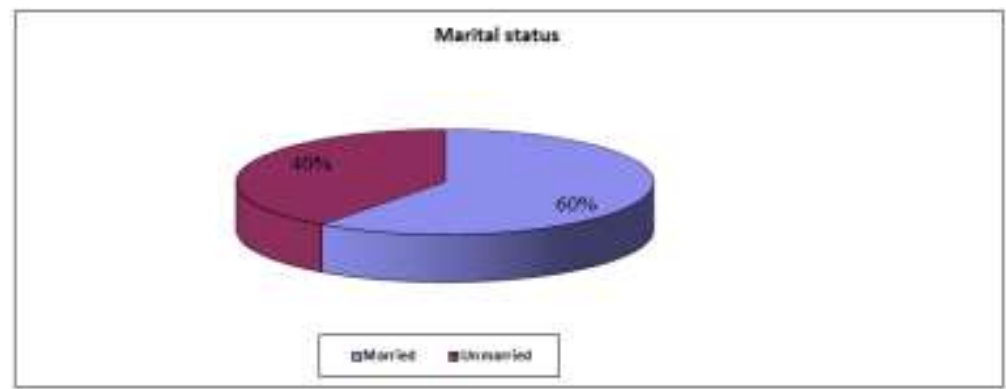

Fig-2: Marital status of the study population $(\mathbf{n}=\mathbf{8 5})$

\section{Socio-economic status of the study population}

Figure 3 showed majority $59 \%$ of the patients came from poor class socioeconomic status followed by $40 \%$ were came from middle class socioeconomic status.

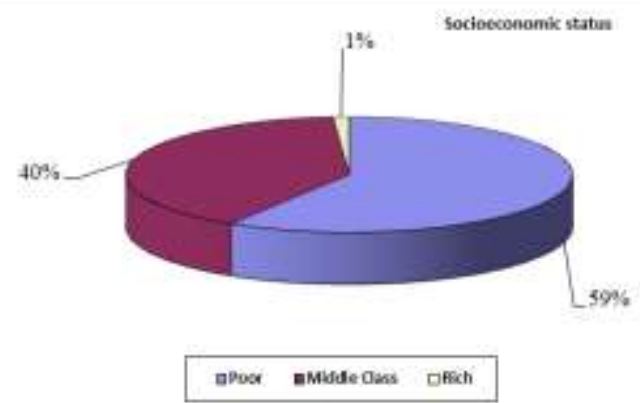

Fig-3: Socio-economic status of the study population $(\mathrm{n}=\mathbf{8 5})$ 


\section{Occupational status of the study population}

Regarding occupational status 33(38.82\%) were house wife, 10(11.76\%) were day laborer, 12(14.12\%) were farmer and $19(22.35 \%)$ was student.

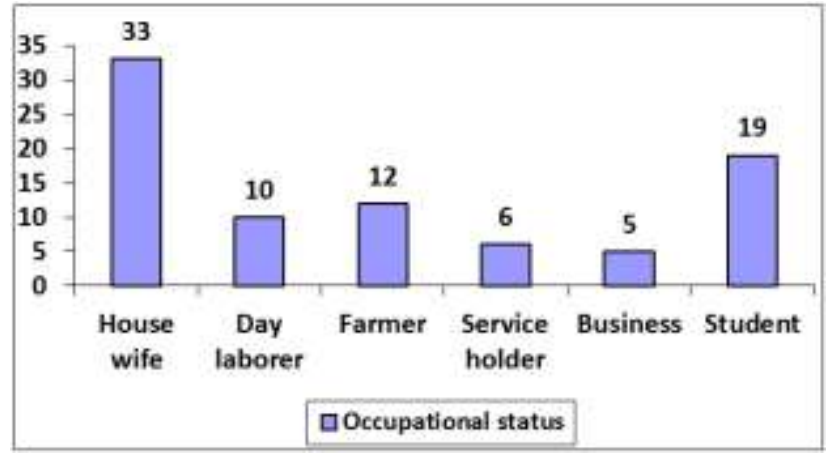

Fig-4: Occupational status of the study population $(n=85)$

\section{Nutritional status of the study population}

Table II showed regarding nutritional status 25(29.4\%) was well nourished, 50(58.8\%) was moderately nourished and $10(11.8 \%)$ was malnourished.

Table-II: Nutritional status of the study population $(n=85)$

\begin{tabular}{|l|c|c|}
\hline & Number & Percentage \\
\hline Well nourished & 25 & 29.4 \\
\hline Moderately nourished & 50 & 58.8 \\
\hline Malnourished & 10 & 11.8 \\
\hline Total & 85 & 100.0 \\
\hline
\end{tabular}

Life style of the study population

Table III showed most $(96.5 \%)$ of the life style was found active.

Table-III: Life style of the study population $(\mathbf{n}=\mathbf{8 5})$

\begin{tabular}{|l|c|c|}
\hline & Number of patients & Percentage \\
\hline Moderately sedentary & 03 & 03.5 \\
\hline Active & 82 & 96.5 \\
\hline Total & 85 & 100.0 \\
\hline
\end{tabular}

Distribution of acute leukemia of the study population

Regarding acute leukemia majority 60(70.6\%) were found AML and 25(29.4\%) ALL

Table-IV: Distribution of acute leukemia of the study population $(n=85)$

\begin{tabular}{|l|c|c|}
\hline Acute leukemia & Number & Percentage \\
\hline ALL & 25 & 29.4 \\
\hline AML & 60 & 70.6 \\
\hline Total & 85 & 100.0 \\
\hline
\end{tabular}

Distribution of serum magnesium level of the study population

Regarding serum magnesium level majority 44(51.8\%) was found hypomagnesaemia followed by 38(44.7\%) were normal magnesium and $03(3.5 \%)$ were hypermagnesaemia

Table-V: Distribution of serum magnesium level of the study population $(n=85)$

\begin{tabular}{|l|c|c|}
\hline Serum magnesium & Normal & Percentage \\
\hline Hypomagnesaemia & 44 & 51.8 \\
\hline Normal & 38 & 44.7 \\
\hline Hypermagnesaemia & 3 & 3.5 \\
\hline Total & 85 & 100.0 \\
\hline
\end{tabular}




\section{DISCUSSION}

In present study observed that the mean age was found $36.17( \pm 19.15)$ years, majority age group was found 10-40 years of age which was (62.4\%). Similar observation was found in Demir et al. study they showed that the average age of patients was $38.08 \pm 11.22$ years (range 24-56)[9]. In study of Merza et al. also observed similar observation [10].

In present study regarding gender $55 \%$ were found male and $45 \%$ were found female. In study of Demir et al. observed that out of 42 cases $14(33.3 \%)$ of them were females and the other $28(66.7 \%)$ person were males [9]. In study of Merza et al. observed acute leukemia group composed of 42-person (AML: 38; ALL: 4$), 14(33.3 \%)$ of them were females and the other $28(66.7 \%)$ person were males [10].

In present study investigation of the population, it was reported that mean serum sodium was $136.00 \pm 4.54 \mathrm{mmol} / \mathrm{L}$, serum potassium was $3.77 \pm 0.49$ $\mathrm{mmol} / \mathrm{L}$, serum chloride was $101.85 \pm 11.05 \mathrm{mmol} / \mathrm{L}$, serum magnesium was $1.80 \pm 0.54 \mathrm{mg} / \mathrm{dL}$, serum albumin was $34.56 \pm 6.47 \mathrm{~g} / \mathrm{L}$, serum calcium was $8.16 \pm 1.14 \mathrm{mg} / \mathrm{dL}$, serum creatinine was $0.78 \pm 0.18$ $\mathrm{mg} / \mathrm{dl}$, RBS was $5.98 \pm 1.22 \mathrm{mmol} / \mathrm{l}, \mathrm{Hb} \%$ was $8.75 \pm 1.97 \mathrm{gm} / \mathrm{dl}$, ESR was $73.93 \pm 34.24 \mathrm{~mm} / 1^{\text {st }}$ hour, platelets count was $77.86 \pm 87.28 \times 10^{9} / \mathrm{L}$, TWBC was $50.07 \pm 70.17 \times 10^{9} / \mathrm{L}$ and blast was $62.38 \pm 22.53 \%$. In study of Demir et al. observed that the mean serum creatinine was found $0.85 \pm 0.32 \mathrm{mg} / \mathrm{dL}, \mathrm{Hb} \%$ was $8.93 \pm 0.91 \mathrm{gm} / \mathrm{dl}$, plateletes count $36.4 \pm 11.7 \times 10^{9} / \mathrm{L}$, mean WBC $51.5 \pm 35.1 \times 10^{9} / \mathrm{L}$.

In present study observed that regarding acute leukemia majority 60(70.6\%) were found AML and 25(29.4\%) ALL. Similar observation was found Demir et al. they showed Acute leukemia group composed of 42 person (AML: 38(90.5\%; ALL: 4(9.5\%).

In present study observed that the mean serum magnesium was found $1.56 \pm 0.60 \mathrm{mg} / \mathrm{dl}$ in ALL patients and $1.89 \pm 0.49 \mathrm{mg} / \mathrm{dl}$ in AML patients which was significantly lower in ALL patient than AML patients ( $\mathrm{p}=0.009$ ). Mean serum Sodium, Potassium and Chloride were not significantly associated with ALL and AML patients. Merza et al. study observed that the mean concentration of serum magnesium (S.Mg) $(\mathrm{mg} / \mathrm{dl})$ in All 1.623 $( \pm 0.453)(\mathrm{mg} / \mathrm{dl})$, AML were 1.737 $( \pm 0.385)(\mathrm{mg} / \mathrm{dl})$. Milionis et al. study reported that there were no significant differences in the incidence of serum Sodium, Potassium and Chloride between patients with AML and ALL, which was more frequently observed in AML patients [13].

In present study regarding serum magnesium level majority $44(51.8 \%)$ was found hypomagnesaemia followed by $38(44.7 \%)$ were normal magnesium and 03(3.5\%) were hypermagnesaemia. In study of Demir et al. observed that the serum levels of $\mathrm{Mg}$ were significantly lower in with acute leukemia patients than in the controls $(\mathrm{p}<0.001)$ [9]. The decreased $\mathrm{S}[\mathrm{Mg}]$ in ALL patients $(65.7 \%)$ can be explained in accordance with the findings of Sahin et al. and Orhun et al. [11]. Moreover, Guo et al. reported that hypomagnesemia was a result of movement of extracellular $\mathrm{Mg}$ into the skeleton through bone formation after initiation of treatment for ALL [12].

The normal $\mathrm{S}[\mathrm{Mg}]$ indicated by $(38.2 \%)$ of total patients is in accordance with the observation made by Sahin et al. [11]. Other workers had also reported similar findings on the normal and decreased $\mathrm{S}[\mathrm{Mg}]$ in patients with malignant disorders Atkinson et al. and Milionis et al. showed a controversial results that may have been related to the fact that $S[\mathrm{Mg}]$ are not always stable and may be affected by variable factors [13]. Thus, measurement of hair $[\mathrm{Mg}]$ seems to be a better indicator in the detection of its chronic deficiency as recorded by Sahin et al. and Donma et al. [11]. The increased $\mathrm{S}[\mathrm{Mg}]$ represented as $3.6 \%$ in ALL are cases of hypermagnesemia. Conditions that interfere with the glomerular filtration (e.g. renal glomerular dysfunction) result in the retention of $\mathrm{Mg}$ and hence elevation of serum level [14]. Further work on the measurement of urine $[\mathrm{Mg}]$ would be valuable in distinguishing renal losses of $\mathrm{Mg}$ from other causes of hypomagnesemia.

\section{Conclusion}

Significantly lower serum magnesium level was found in newly diagnosed acute leukemia patients. Among them significantly lower in ALL patients than AML patients. Half of the acute leukemia patients were found hypomagnesaemia.

\section{REFERENCES}

1. Ferlay J, Shin HR, Bray F, Forman D, Mathers C, Parkin DM. Cancer Incidence and Mortality Worldwide: IARC CancerBase No. 10. GLOBOCAN 2008 v1. 2, Lyon, France: International Agency for Research on Cancer; 2010. Lancet Oncol. 2012;13(6):607-15.

2. Jönsson-Videsäter K, Björkhem-Bergman L, Hossain A, Söderberg A, Eriksson LC, Paul C, Rosén A, Björnstedt M. Selenite-induced apoptosis in doxorubicin-resistant cells and effects on the thioredoxin system. Biochemical pharmacology. 2004 Feb 1;67(3):513-22.

3. Everington T, Liesner RJ and Goldstone AH. 'The Acute Leukaemias', In 'ABC of Clinical Haematology', Ed Provan D. BMJ Books, London. 2003: 23-7.

4. Mahabir S, Spitz MR and Barrera SL.' Dietary zinc, copper and selenium, and risk of lung cancer', Int J Cancer. 2007; (120):1108-15.

5. Shenkin A. 'Micronutrients and outcome', Nutrition.1997; 13: 825-8.

6. Tessmer CF Hrgovic M, Thomas FB, Wilbur J and Mumford DM. 'Long term serum copper studies in 
acute leukemia in children', Cancer.1972; (30): 3565.

7. Milionis HJ, Bourantas CL, Siamopoulos KC, Elisaf MS. Acid-base and electrolyte abnormalities in patients with acute leukemia. American journal of hematology. 1999 Dec;62(4):201-7.

8. Rude R. 'Magnesium', In: Biochemical and Physiological Basis of Human Nutrition, edited by Stipanuk M, Orlando, Saunders. 2000: 671-685.

9. Demir C, Demir H, Esen R, Sehitogullari A, Atmaca M and Alay M. 'Altered Serum Levels of Elements in Acute Leukemia Cases in Turkey', Asian Pacific J Cancer Prev. 2011; 12: 3471-4.

10. Merza WM, Daoud MS, Jawad AM. Serum magnesium concentration in patients with leukemia and lymphoma. Journal of the Faculty of Medicine Baghdad. 2009 Apr 1;51(1):101-4.
11. Sahin G, Erten U, Duru F, Biraen D, Kuksek N. High prevalence of chronic magnesium deficiency in children with acute lymphoblastic leukemia and malignant lymphoma. Leuk Lymphoma. 2000;39(5-6):555-62.

12. Guo CY, Halton JM, Barr R and Atkinson SA. 2004, 'Hypomagnesemia associated with chemotherapy in patients treated for acute lymphoblastic leukemia: Possible mechanisms', Oncol. Rep. 2004; 11(1): 185-9.

13. Atkinson, SA, Halton, JM, Bradley, C, Wu, B \& Barr, RD 1998, 'Bone and mineral abnormalities in acute childhood lymphoblastic leukemia: Influence of disease, drugs and nutrition', Int. J. Cancer Supp.1998; 11: 35-39.

14. Whitby LG, Percy-Robb IW, Smith AF. Lecture notes on clinical chemistry. Blackwell Scientific Publications; 1975. 